\title{
Vegetational Diversity Analysis across Different Habitats in Garhwal Himalaya
}

\author{
Vardan Singh Rawat ${ }^{1,2}$ and Jagdish Chandra ${ }^{2}$ \\ ${ }^{1}$ Government Inter College Bagwadi, P.O. Bagwadi, Block Thalisain, Pauri Garhwal 246285, India \\ ${ }^{2}$ Department of Botany, Kumaun University, D.S.B. Campus, Nainital, Uttarakhand, India
}

Correspondence should be addressed to Vardan Singh Rawat; singhvardan@rediffmail.com

Received 16 February 2014; Accepted 21 May 2014; Published 7 July 2014

Academic Editor: Muhammad Y. Ashraf

Copyright (c) 2014 V. S. Rawat and J. Chandra. This is an open access article distributed under the Creative Commons Attribution License, which permits unrestricted use, distribution, and reproduction in any medium, provided the original work is properly cited.

Four forest sites varying in vegetation types were studied along an altitudinal range between 2200 and 2500 m. Maximum tree, shrub, and herb species were recorded on stream bank site (22, 25, and 54, resp.). Pteridophytes and bryophytes species richness was maximum on moist site ( 4 and 5 , resp.). The number of climbers was greater in moist and dry habitats ( 7 species each). Parasitic species were restricted only on dry and stream bank habitats. Restricted tree and shrub species were greater on stream bank site and dry site, respectively. The herb and climber species were greater on moist site. The distribution and species richness pattern in this elevational range largely depend on the altitude and climatic variables. Along the entire range of Garhwal Himalaya, the overlapping among species regimes is broad; therefore, transitional communities having mixture of many species and zones are present. The present study indicates that the opening canopies increase the richness of tree, shrub, herb, and climbers.

\section{Introduction}

The Himalaya constitutes one of the richest and most unusual ecosystems on Earth [1]. Indian Himalayan region covers approximately an area of $4,19,873 \mathrm{Km}^{2}$. The unique physiography, climatic conditions, and soil characteristics of the area have resulted in a variety of habitats and a significant biological diversity. The Himalayan region supports about 8000 plant species $(47.06 \%$ of the total flowering plants of India) of which $30 \%$ are endemics among natives, $10.2 \%$ trees, $8.44 \%$ wild edibles, and over $15 \%$ medicinal. The dependence of human and livestock on this rich plant diversity is wellknown phenomenon since time immemorial [2].

Forest composition, species richness, diversity pattern, and spatial or temporal distribution are important ecological attributes significantly correlated with prevailing environmental as well as anthropogenic variables [3-5]. There are a large number of environmental factors which influence the species richness and composition, such as elevation and habitat [6]. Slobodkin and Sanders [7] opined that floristic diversity of any community is a function of severity, variability, and predictability of the environment in which it develops. The distribution of communities varies in relation to the physical as well as biotic features.

The phytosociological study incorporates mainly the description and functional aspects of the vegetation. It also provides information about composition of trees, shrubs, herbs, and climbers. It is assumed that the dominating plant species actually determine the structure of a community and not any other characteristic [8]. The structure of a vegetational unit depends upon the species composition, their relative number, and diversity. Plant diversity has been said to increase in a successional sequence, leading to climax stage. There is growing awareness that biodiversity is closely linked with long term health and vigour of the biosphere, as an indicator of global environment and also as a regulator of ecosystem functioning [9].

The present study identifies the variation in species richness and other community characteristics in elevation ranging from 2200 to $2500 \mathrm{~m}$ in the Garhwal Himalaya. 


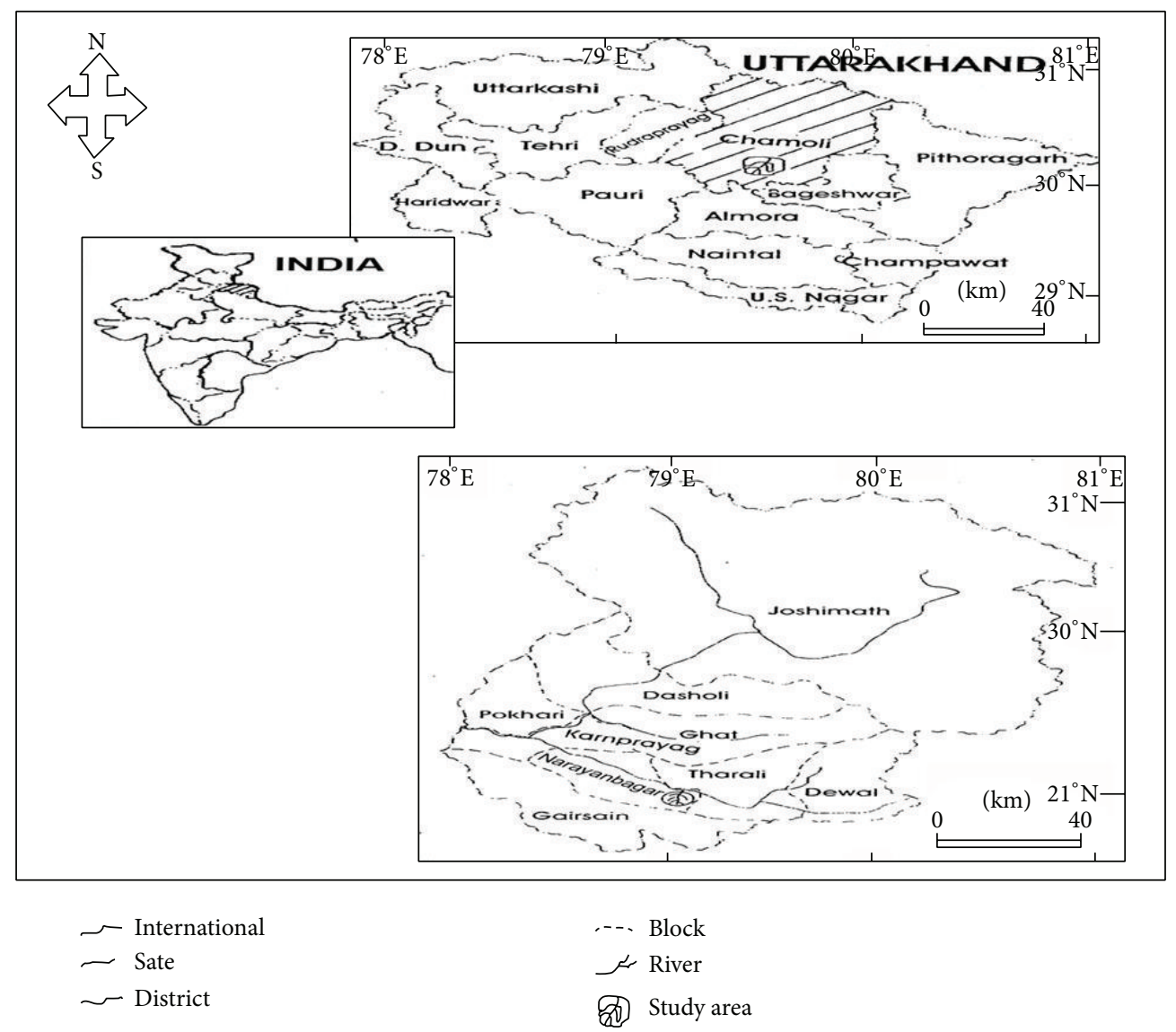

FIGURE 1: Location map of the study area.

\section{Materials and Methods}

2.1. Site Description. The present study was conducted in the western Pindar region of Uttarakhand $\left(30^{\circ} 2^{\prime} 43^{\prime \prime} \mathrm{N}\right.$ and $30^{\circ} 3^{\prime} 27^{\prime \prime} \mathrm{N}$ latitude and $79^{\circ} 24^{\prime} 43^{\prime \prime}$ and $79^{\circ} 26^{\prime} 46^{\prime \prime} \mathrm{E}$ longitude, Figure 1). The basic climatic pattern is governed by monsoon pattern of rainfall. The monsoon strikes this area from June to September and snowfall begins in November and continues till March, but on the high peaks it keeps on falling throughout the season. Cloud and fog formation are regular features and the period of clear sky is limited for only a few morning hours each day. Meteorological data was collected from K. V. K. Gwaldam, Chamoli district of Uttarakhand [5]. The average monthly maximum temperature was $25.5^{\circ} \mathrm{C}$ in June and average monthly minimum temperature was $2.5^{\circ} \mathrm{C}$ in February. The average monthly maximum rainfall was $510.8 \mathrm{~mm}$ in August, and minimum monthly average rainfall was $10.4 \mathrm{~mm}$ in November (Figure 2). The study area falls under the temperate Himalayan forests. This area is covered by oak mixed forest and conifer oak mixed forest. The dominated tree species are Lyonia ovalifolia, Quercus leucotrichophora, Quercus glauca, Quercus floribunda, Quercus semecarpifolia, Rhododendron arboreum, Myrica esculenta, Cedrus deodara, Cornus capitata, and Aesculus indica.

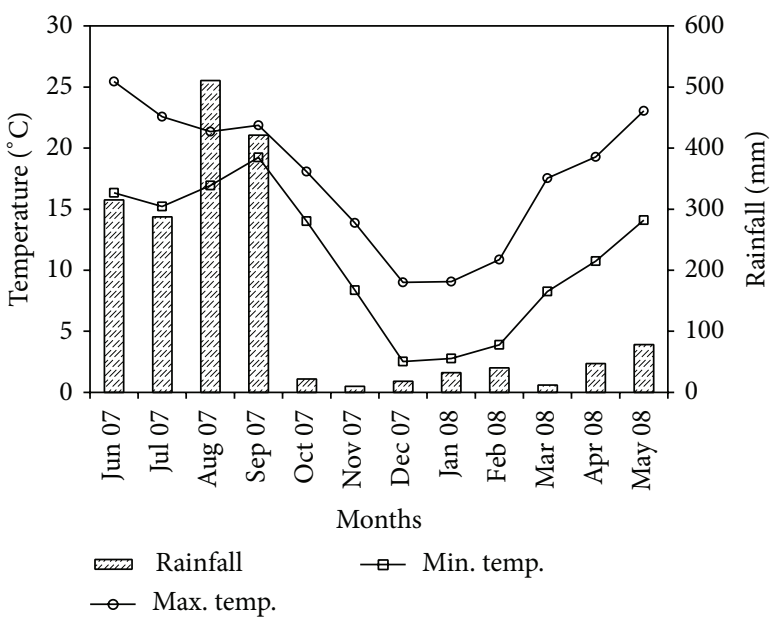

FIGURE 2: Meteorological data of the study area.

\section{Methods}

The detailed field surveys were carried out to study the vegetational data and finally four sites or habitats, namely, stream bank, dry, ridge, and moist sites, were selected at 
higher elevation (2200 to $2500 \mathrm{~m}$ ). The selected sites were visited frequently from year 2005 to year 2008 for collection of plant species. Efforts were made to collect almost all the plant species present in the study area (represent > $90 \%$ species). The plant species were collected annually and brought to the laboratory, preserved, mounted on herbarium sheets, and identified according to the flora of Garhwal Himalaya [10], flora of Chamoli [11], flora of Himalaya [12], name changes in flowering plants of India and adjacent regions [13], and flowering plants of India and Bhutan [14]. The plant species collected were categorized as follows:

tress: large woody perennials, top canopy, or subcanopy layer in forest ( $>4 \mathrm{~m}$ height);

shrubs: small woody perennials, about $1-4 \mathrm{~m}$ in height and generally branched at the base;

herbs: small nonwoody annuals or perennials may be erect tall $(<1 \mathrm{~m})$, erect shorts, cushion forming and spreading and grasses and sedges;

climbers: woody or nonwoody annuals and perennial plants, climbing with the help of other substrate (trees, shrubs, tree trunks, rocks, stone, etc.);

tree trunk vegetation: small woody or nonwoody, annual or perennials, and vascular or nonvascular plants grown on the trunk (stem) and categorized as epiphytes, pteridophytes, and bryophytes;

parasites: growing parasitically on different tree and shrub species.

Communities identified on basis of species richness have been compared on the basis of their floristic similarities with each other by computing coefficient of similarity [15] as

$$
\text { Similarity Coefficient }(S)=\frac{2 C}{A+B} \times 100,
$$

where $A=$ species richness in stand " $A$, ," $B=$ species richness in stand " $B$," and $C$ is the sum of common species in two stands $A$ and $B$.

Total species richness was the sum of all species present in a site considering all samples and mean species richness was determined following Whittaker [16]. Common species between any two sites were also studied. Various species restricted on different sites and elevations were also identified for their distribution. Mean tree species richness was determined in $100 \mathrm{~m}^{2}$, shrubs in $25 \mathrm{~m}^{2}$, herbs in $1 \mathrm{~m}^{2}$, and climbers in $25 \mathrm{~m}^{2}$ plots. The data were analyzed using SPSS Version 12 . $t$-test was applied to differentiate the species richness between elevations following Snedecor and Cochran [17].

\section{Results}

A total of 413 plants species were recorded at higher elevation, of which 75 were tree, 86 shrub, 193 herb, 25 climber, 12 pteridophyte, 11 bryophyte, 7 epiphyte, and 4 parasitic species. Maximum (22) tree species were recorded on stream bank site and minimum (17 species) on ridge site (Figure 3). Cinnamomum tamala, Cedrus deodara, Cornus capitata, Lyonia

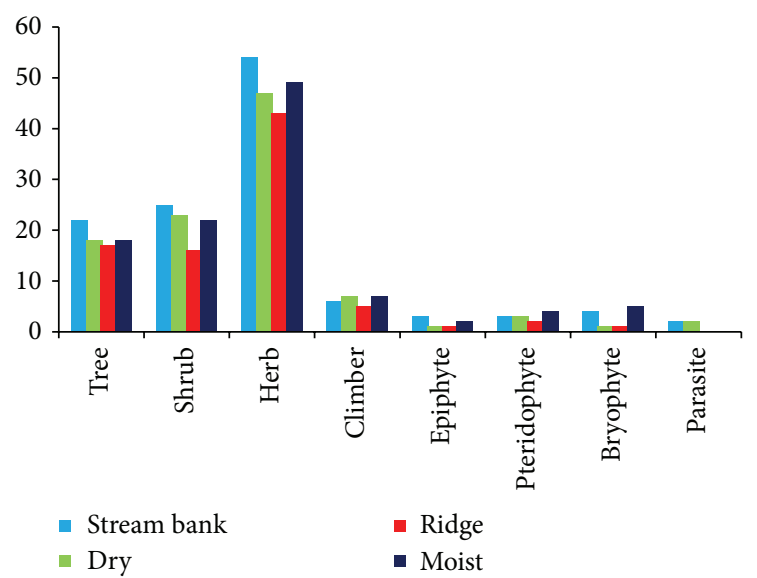

FIGURE 3: Total species richness of vegetation across different sites; the number of species is on $y$-axis and the vegetation type is on $x$ axis.

ovalifolia, Machilus duthiei, Myrica esculenta, Quercus floribunda, Quercus leucotrichophora, and Symplocos chinensis were widely distributed and present on all the sites. Maximum (25) shrub species were recorded on stream bank site and minimum (16 species) on ridge site (Figure 3). Berberis asiatica, Berberis chitria, Daphne cannabina, Desmodium gangenticum, Eupatorium adenophorum, Indigofera dosua, Plectranthus japonicus, Rubus paniculatus, and Viburnum coriaceum were widely distributed and present on all the sites. Maximum (54) herb species were present on stream bank site and minimum (43 species) on ridge site (Figure 3). Ainsliaea aptera, Ajuga parviflora, Anaphalis busua, Anaphalis cinnamomea, Carex condensata, Conyza japonica, Desmodium polycarpum, Erigeron karvinskianus, Galium rotundifolium, Gerbera macrophylla, Geum elatum, Ocimum tenuiflorum, Oplismenus compositus, Ranunculus diffusus, Scutellaria angulosa, Senecio rufinervis, Verbascum thapsus, and Viola canescens were widely distributed and present on all the sites.

Maximum climbers were recorded on dry site and moist site (7 species each) and minimum (5 species) on ridge site (Figure 3). Parthenocissus himalayana and Smilax aspera were widely distributed and present on all the sites. Three epiphytes were recorded on stream bank site and only one was recorded on dry and ridge sites (Figure 3). Roscoea procera was widely distributed and present on stream bank, ridge, and moist sites. Maximum four pteridophytes were present on moist site and only 2 species were recorded on ridge site (Figure 3). Araiostegia pseudocystopteris and Lepisorus sesquipedalis were widely distributed and present on all sites. Maximum five bryophytes were present on moist sites and only one was recorded on dry and ridge site each (Figure 3). Brachythecium buchananii was widely distributed and recorded on dry and moist sites. Two parasites were recorded on dry and ridge sites (Figure 3). Vescum album was widely distributed and present on dry and ridge sites.

Maximum species relationships (tree, shrub, herb, and climber) across different sites were recorded for stream bank and dry sites and minimum species relationships were recorded for dry and moist sites. Maximum tree trunk species 


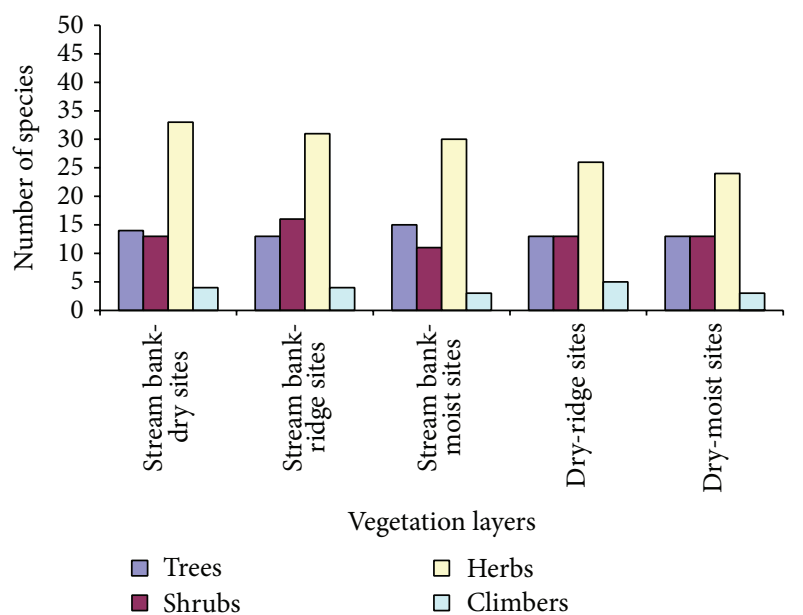

(a)

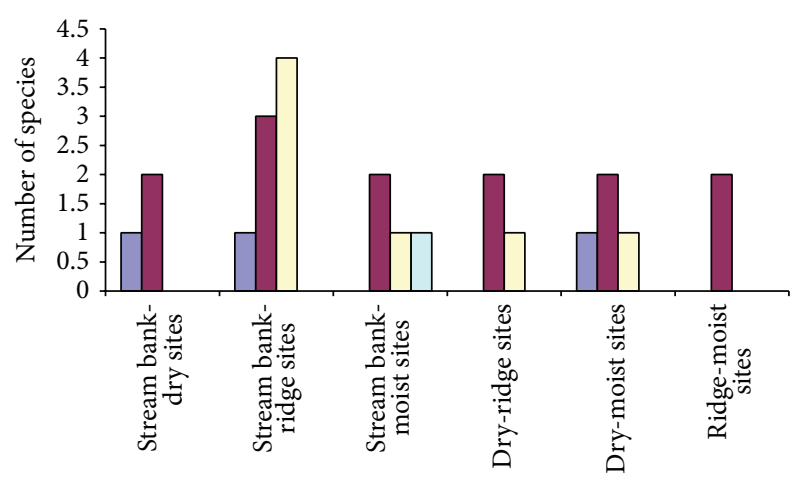

Tree trunk vegetation

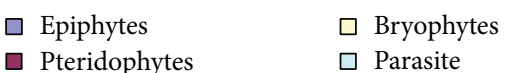

(b)

FIGURE 4: Species relationship between different sites at higher elevation.

TABLE 1: Mean species richness in different sites of high elevation.

\begin{tabular}{lcccc}
\hline Site & $\begin{array}{c}\text { Tree } \\
\left(\text { species } / 100 \mathrm{~m}^{2}\right)\end{array}$ & $\begin{array}{c}\text { Shrub } \\
\left(\text { species } / 25 \mathrm{~m}^{2}\right)\end{array}$ & $\begin{array}{c}\text { Herb } \\
\left(\text { species } / 1 \mathrm{~m}^{2}\right)\end{array}$ & $\begin{array}{c}\text { Climber } \\
\left(\mathrm{species} / 25 \mathrm{~m}^{2}\right)\end{array}$ \\
\hline Steam bank & $4.9 \pm 0.3$ & $3.2 \pm 0.3$ & $6.4 \pm 0.3$ & $0.9 \pm 0.2$ \\
Dry & $4.0 \pm 0.3$ & $4.6 \pm 0.2$ & $7.0 \pm 0.3$ & $0.8 \pm 0.2$ \\
Ridge & $3.5 \pm 0.2$ & $3.4 \pm 0.3$ & $6.7 \pm 0.3$ & $0.7 \pm 0.1$ \\
Moist & $4.3 \pm 0.2$ & $4.2 \pm 0.3$ & $8.9 \pm 0.4$ & $1.3 \pm 0.1$ \\
\hline
\end{tabular}

relationships across different sites were recorded between stream bank and ridge sites. Only pteridophyte was recorded between ridge and moist sites (Figure 4).

The mean tree and shrub species richness was higher on stream bank site $(4.9 \pm 0.3)$ and dry site $(4.6 \pm 0.2)$, respectively. Minimum mean tree and shrub species richness was recorded on ridge $(3.5 \pm 0.2)$ and stream bank sites $(3.2 \pm$ $0.3)$, respectively. Mean herb and climber species richness was maximum on moist site $(8.9 \pm 0.4$ and $1.3 \pm 0.1$, resp. $)$ and minimum on stream bank $(6.4 \pm 0.3)$ and ridge sites $(0.7 \pm 0.1$; Table 1).

The similarity index of tree layer indicates that maximum similarity was in dry and ridge sites $(85.7 \%)$ and minimum in stream bank and ridge sites (71.8\%). In the shrub layer, maximum similarity was recorded in stream bank and dry sites (75\%) and minimum in dry and ridge sites (56.4\%). Examining the herb and climber layer, maximum similarity was observed in stream bank and ridge sites (68\%) and stream bank and dry sites (76.92\%), respectively (Table 2).

ANOVA test indicates that mean trees, shrubs, and herbs richness was significant $(P<0.001)$ and varied among and between the sites.

\section{Discussion}

Species richness, diversity, heterogeneity, and spatial or temporal distribution in an area are the central subjects of community ecology [5]. There are a large number of
TABLE 2: Percent similarity of different sites at high elevation.

\begin{tabular}{lcccc}
\hline Site and habitat & \multicolumn{5}{c}{ Stream bank } & Dry & Ridge & Moist \\
\hline \multicolumn{5}{c}{ Tree layer } \\
Stream bank & 100.00 & 80.00 & 71.79 & 65.00 \\
Dry & - & 100.00 & 85.71 & 72.22 \\
Ridge & - & - & 100.00 & 74.29 \\
Moist & - & - & - & 100.00 \\
\hline \multicolumn{5}{c}{ Shrub layer } \\
Stream bank & 100.00 & 75.00 & 63.41 & 68.07 \\
Dry & - & 100.00 & 56.41 & 57.78 \\
Ridge & - & - & 100.00 & 68.42 \\
Moist & - & - & - & 100.00 \\
\hline \multicolumn{5}{c}{ Herb layer } \\
Stream bank & 100 & 63.37 & 68.04 & 60.19 \\
Dry & - & 100.00 & 66.67 & 54.17 \\
Ridge & - & - & 100.00 & 52.17 \\
Moist & - & - & - & 100.00 \\
\hline \multicolumn{5}{c}{ Climber layer } \\
Stream bank & 100.00 & 76.92 & 72.73 & 61.54 \\
Dry & - & 100.00 & 50.00 & 71.43 \\
Ridge & - & - & 100.00 & 50.00 \\
Moist & - & - & - & 100.00 \\
\hline
\end{tabular}

environmental factors which influence the species richness and composition [6]. Sagar et al. [18] opined that tree 
species diversity varied greatly from place to place mainly due to variation in biogeography, habitat, and disturbance. Srivastava et al. [19] reported that the community characters differ among aspect, slope, and altitude even in the same vegetation type.

In the present study, the tree, shrub, and herb species richness was maximum on stream bank site $(22,25$, and 54 , resp.) and minimum on ridge site (17, 16, and 43, resp.). Pteridophytes and bryophytes species richness was maximum on moist site ( 4 and 5 , resp.). It indicates that stream bank and moist habitat favour the regeneration of different vegetation because of the availability of sufficient moisture for seed germination and survival of seedlings. In the present study, the tree species richness was more or less similar to temperate oak and oak mixed forests $(3-43)[6,20]$. The shrub and herb species richness value in the present study falls between the values reported earlier by different workers for evergreen Himalayan forests $[21,22]$. The number of climbers was greater in moist and dry habitats (7 species each). Parasitic species were restricted only on dry and stream bank sites. Thus, harsh conditions favored the growth and development of parasites. The mean tree species richness was higher on stream bank site. This was due to the presence of high tree density on this site. Between the sites, the percent similarity of tree species was greater between dry and ridge sites. Both of the sites were closely located. However, the percent similarity of climbers was greater between stream bank and dry sites. Restricted tree species was greater on stream bank site. Shrub restricted species was greater on dry site. The herb and climber species were greater on moist site. Less information was available for central Himalayan forest ecosystems as far as comparison of sites located at different habitats and distribution of restricted species is concerned. Along the entire altitudinal range of Garhwal Himalaya, the overlapping among species regimes is broad; therefore, transitional communities having mixture of many species and zones are present. The present study indicates that the opening canopies increase the richness of tree, shrub, herb, and climbers. This was due to penetration of abundant light on the forest floor and warm temperature was favorable for the regeneration of more tree, shrub, herb, and climbers.

\section{Conflict of Interests}

The authors declare that there is no conflict of interests regarding the publication of this paper.

\section{References}

[1] J. Salick, F. Zhendong, and A. Byg, "Eastern Himalayan alpine plant ecology, Tibetan ethnobotany, and climate change," Global Environmental Change, vol. 19, no. 2, pp. 147-155, 2009.

[2] U. Dhar, R. S. Rawal, and S. S. Samant, "Structural diversity and representativeness of forest vegetation in a protected area of Kumaun Himalaya, India: implications for conservation," Biodiversity \& Conservation, vol. 6, no. 8, pp. 1045-1062, 1997.

[3] S. Gairola, R. S. Rawal, and N. P. Todaria, "Forest vegetation patterns along an altitudinal gradient in sub-alpine zone of West
Himalaya, India," African Journal of Plant Science, vol. 2, no. 6, pp. 42-48, 2008.

[4] I. Ahamad, M. S. A. Ahmad, M. Hussain, M. Ashraf, and M. Ashraf, "Spatiotemporal variations in soil characteristics and nutrient availability in open scrub type semi-arid rangelands of typical sub-mountainous Himalayan tract," Pakistan Journal of Botany, vol. 43, no. 1, pp. 565-571, 2011.

[5] V. S. Rawat and J. Chandra, "Tree layer vegetational analysis in temperate forest of Uttarakhand," Nature and Science, vol. 10, no. 10, pp. 167-171, 2012.

[6] J. Chandra, V. S. Rawat, Y. S. Rawat, and J. Ram, "Vegetational diversity along an altitudinal range in Garhwal Himalaya," International Journal of Biodiversity and Conservation, vol. 2, no. 1, pp. 14-18, 2010.

[7] L. B. Slobodkin and H. L. Sanders, "On the contribution of environmental predictability to species diversity," Brookhaven Symposia in Biology, vol. 22, pp. 82-93, 1969.

[8] E. P. Odum, Fundamentals of Ecology, W.B. Saunders, Philadelphia, Pa, USA, 1971.

[9] O. T. Solbrig, Ed., From Genes to Ecosystems: A Research Agenda for Biodiversity, International Union of Biological Sciences, Paris, France, 1991.

[10] R. D. Gaur, Flora of the District Garhwal North West Himalaya with Ethnobotanical Notes, Transmedia, Srinagar, India, 1999.

[11] B. D. Naithani, Flora of Chamoli, vol. 1-2, Botanical Survey of India, New Delhi, India, 1984.

[12] O. Polunin and A. Stainton, Flowers of the Himalaya, Oxford University Press, Oxford, UK, 1984.

[13] S. S. R. Benuett, Name Change in Flowing Plant of India and Adjacent Regions, Triseas Publisher, Dehradun, India, 1987.

[14] H. N. Naithani, Flowering Plant of India, Nepal \& Bhutan Surya, Dehradun, India, 1990.

[15] T. Sorensen, A Method of Establishing Groups of Equal Amplitude in Plant Sociology Based on Similarity of Species Content and Its Application to Analyses of the Vegetation on Danish Commons, vol. 5, Videnski Selskab Biologiske Skrifter, 1948.

[16] R. H. Whittaker, "Evolution and measurement of species diversity," Taxon, vol. 21, pp. 213-251, 1972.

[17] G. W. Snedecor and W. G. Cochran, Statistical Methods, Oxford, IBM, New Delhi, India, 1967.

[18] R. Sagar, A. S. Raghubanshi, and J. S. Singh, "Tree species composition, dispersion and diversity along a disturbance gradient in a dry tropical forest region of India," Forest Ecology and Management, vol. 186, no. 1-3, pp. 61-71, 2003.

[19] A. K. Srivastava, A. Tewari, S. Shah, and B. Tewari, "Species composition and regeneration pattern along a transect perpendicular to a river course in foot hill Deciduous tropical forest of Kumaun," Indian Journal of Forestry, vol. 1, no. 31, pp. 7-12, 2008.

[20] G. Kharkwal, P. Mehrotra, and Y. P. S. Rawat, "Species diversity and related parameters in forests of the Central Kumaun Himalaya, India," Journal of Botanical Research, vol. 3, no. 1, pp. 177-184, 2007.

[21] J. Ram, B. Tewari, and N. Arya, "Variation in plant biodiversity of chir-pine and banj-oak forests of Uttaranchal Himalaya," in Biodiversity Resources Management and Sustainable Use, Muthuchelian, Ed., pp. 54-56, Centre for Biodiversity and Forest Studies, Madurai, India, 2004.

[22] G. Kharkwal, P. Mehrotra, and Y. P. S. Pangtey, "Comparative studies on species richness, diversity and composition of oak forests in Nainital district, Uttaranchal," Current Science, vol. 89, no. 4, pp. 668-672, 2005. 

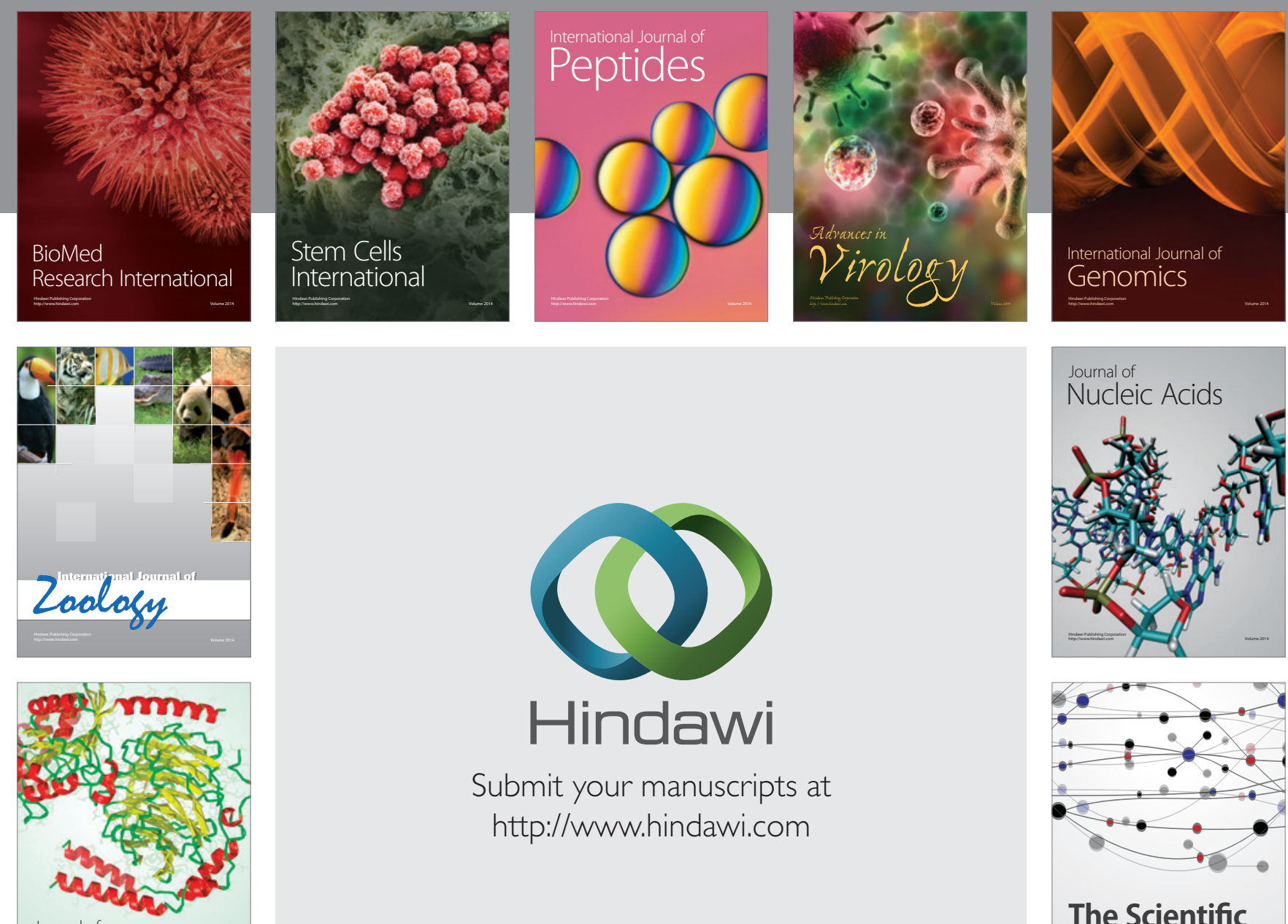

Submit your manuscripts at

http://www.hindawi.com

Journal of
Signal Transduction
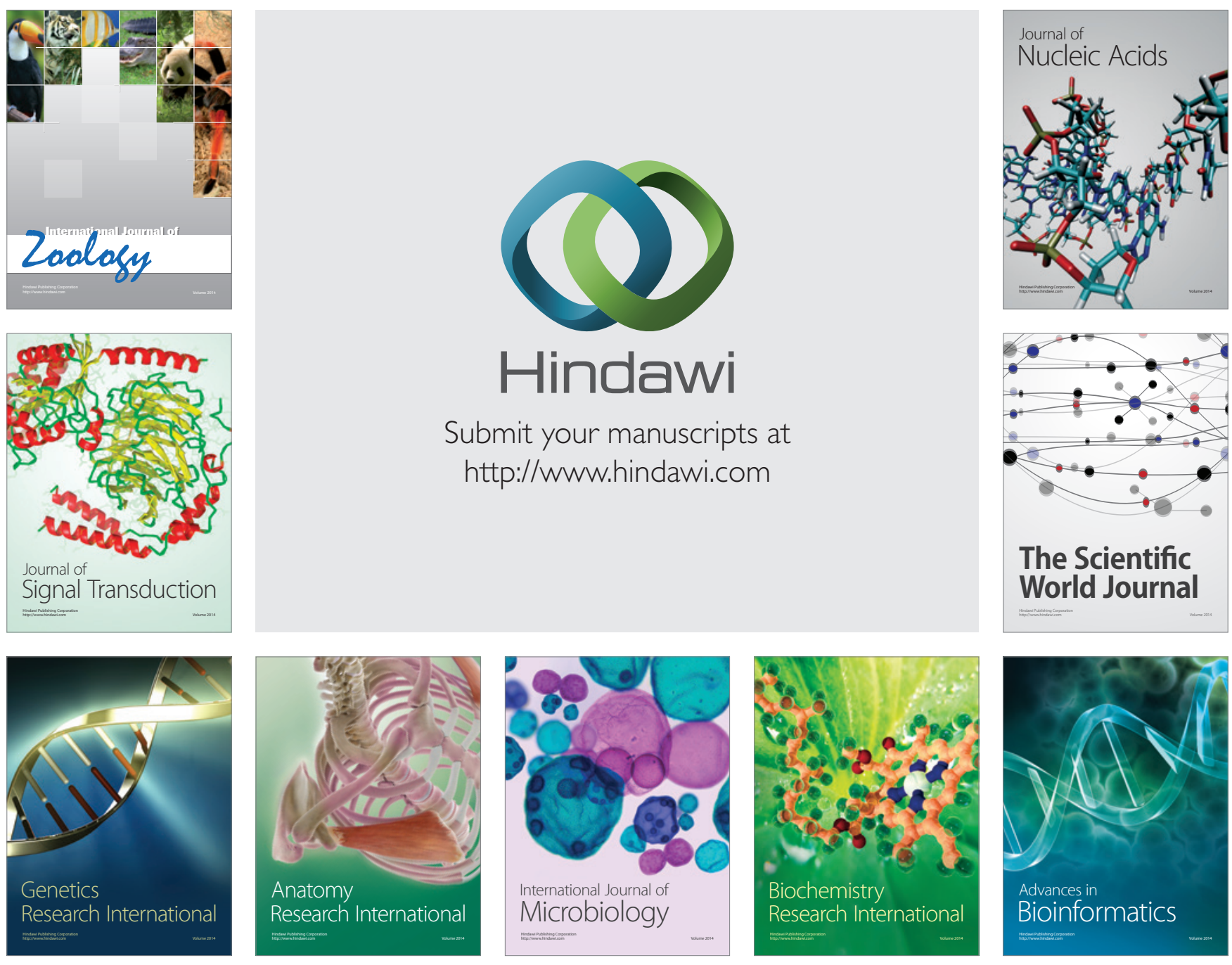

The Scientific World Journal
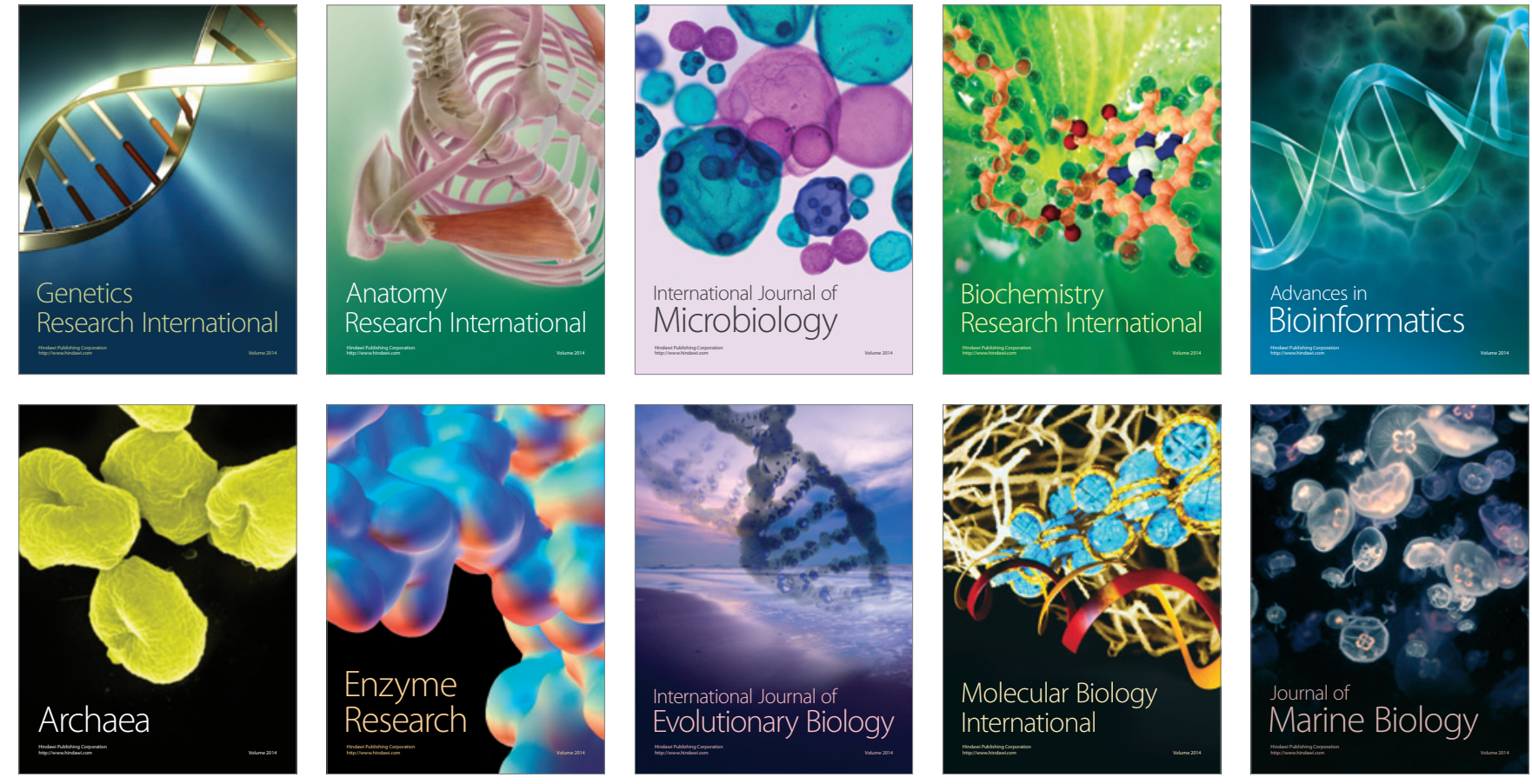